\title{
Development of a cake rich in resistant starch with good sensory acceptance
}

\section{Desenvolvimento de bolo rico em amido resistente e com boa aceitação sensorial}

\author{
Iohana Scarlet Almeida Guedes ${ }^{1}$; Eliseth de Souza Viana2*; Ronielli Cardoso Reis²; \\ Fabrine Dias Santos 3 ; Paulo Roberto Ribeiro Mesquita ${ }^{4}$
}

\section{Highlights}

The incorporation of GBF increased the resistant starch content of the cake.

Cakes with $14 \%$ and $18 \%$ GBF had better flavor, softness, and overall acceptance.

Cakes with GBF showed high sensory acceptance and purchase intent.

\begin{abstract}
The objective of this study was to develop a cake rich in resistant starch, with green banana flour (GBF), of good sensory acceptance. In step 1, four cake formulations were prepared with increasing concentrations of GBF and evaluated for acceptability and purchase intention. In step 2, four new formulations were made by modifying the most accepted formulation in step 1, in addition to the formulation without GBF (control). The resistant starch content, proximate composition, total calorific value, and sensory acceptance data were obtained. The formulation with cocoa powder and dried banana (E1F4) achieved $97.78 \%$ overall acceptance and higher purchase intent. In step 2, the formulations with 14\% and 18\% GBF were the most accepted for flavor, texture/softness, and overall acceptance. Adding the categories of "would certainly buy" and "would probably buy", $53.33 \%$ of consumers would buy the cake with $14 \%$ GBF and $48.89 \%$ would buy the cake containing 18\% GBF. The incorporation of GBF increased the resistant starch contents of the formulations as compared with the control. Ash content was highest in the formulation with $26 \%$ GBF (2.22\%) and lipid content in the control formulation (11.58\%). The treatments did not differ in terms of moisture content. Protein content decreased as the GBF content in the formulations was increased. The total dietary fiber content of the formulations was $9.30 \%$. Carbohydrate content and calorific value also did not vary. The mean values of $L^{*}, a^{*}, b^{*}, C^{*}$, and $h^{*}$ showed that the cakes had an intense dark brown color. In conclusion, the addition of $14 \%$ and $18 \%$ GBF to the cake resulted in a product of high sensory acceptance, with high purchase intent, a resistant starch content 7.21 and 8.34 times higher than those in the control cake.
\end{abstract}

Key words: Functional food. Bakery. Green banana flour.

1 Pharmacy Undergraduate, Faculdade Maria Milza, FAMAM, Governador Mangabeira, BA, Brazil. E-mail iohanascarlet@ hotmail.com

2 Researchers, Empresa Brasileira de Pesquisa Agropecuária, EMBRAPA, Cruz das Almas, BA, Brazil. E-mail: eliseth. viana@embrapa.br; ronielli.reis@embrapa.br

3 Nutrition Undergraduate, FAMAM, Governador Mangabeira, BA, Brazil. E-mail: fabrinedias@hotmail.com

${ }^{4}$ Prof., FAMAM, Governador Mangabeira, BA, Brazil. E-mail: prrmesquita@gmail.com

* Author for correspondence

Received: Apr. 01, 2021 - Approved: Sept. 01, 2021 


\section{Resumo}

O objetivo desse estudo foi desenvolver uma formulação de bolo com farinha de banana verde (FBV), rica em amido resistente e com boa aceitação sensorial. Na etapa 1, foram elaboradas quatro formulações de bolo, com concentrações crescentes de FBV, as quais foram avaliadas quanto à aceitação sensorial e intenção de compra. Na etapa 2 foram feitas quatro novas formulações, modificando-se a formulação mais aceita na etapa 1, e um controle, sem farinha de banana verde. Quantificou-se o teor de amido resistente, estudou-se a composição centesimal, calculou-se o valor calórico total e avaliou-se a aceitação sensorial. A formulação com cacau em pó e banana passa (E1F4) apresentou aceitação global igual a 97,78\% e maior intenção de compra. Na etapa 2, as formulações com 14\% e 18\% de farinha de banana verde foram as mais aceitas para o sabor, textura/maciez e aceitação global. Somando-se as categorias "certamente compraria" e "provavelmente compraria", 53,33\% dos consumidores comprariam o bolo com $14 \%$ de farinha de banana verde e $48,89 \%$ o com $18 \%$. A incorporação de concentrações crescentes de FBV proporcionou aumento nos teores de amido resistente das formulações em relação ao controle. O teor de cinzas foi maior na formulação com $26 \%$ de farinha de banana verde $(2,22 \%)$ e o de lipídeos na formulação controle $(11,58 \%)$. Os tratamentos não diferiram quanto ao teor de umidade. O teor de proteína reduziu, à medida em que o teor de farinha de banana verde foi incrementado nas formulações. O teor de fibra alimentar total das formulações foi igual a 9,30\%. O teor de carboidratos e valor calórico também não variaram. Os valores médios das variáveis $L^{*}, a^{*}, b^{*}, C^{*}$ e h* demonstraram que os bolos apresentaram coloração marrom escura intensa. Conclui-se que a adição de 14\% e 18\% de farinha de banana verde no bolo resultou em um produto com elevada aceitação sensorial, elevada intenção de compra e com teor de amido resistente 7,21 e 8,34 vezes superior ao bolo controle.

Palavras-chave: Alimento funcional. Panificação. Farinha de banana verde.

\section{Introduction}

In the green maturation stage, bananas do not have marked sensory characteristics due to physiological immaturity. However, they have aroused the interest of the food industry and producers for being available throughout the year, minimizing post-harvest losses, and being easy to transport and store, as well as for the possibility of adding value to their cultivation (Pires, Silva, \& Souza, 2014; Campuzano, Rosell, \& Cornejo., 2018).

With the growing and rapid access to information and market trends in the food sector, consumers have increasingly sought healthier products that offer nutritional benefits (Ferronatto, Rossi, \& Cappellari, 2020). Food rich in fiber and resistant starch (RS) fall into this group (Freitas, Silveira, Veras, \& Santos, 2017), which takes the green banana to a prominent position for being a good source of RS (Reis, Viana, Assis, Sena, Souza, \& Amorim, 2019; Campuzano et al., 2018). Additionally, its consumption in the recommended amount directly contributes to the proper functioning of the immune system and intestinal function (Öztürk \& Mutlu, 2019).

Nonetheless, green banana is not consumed in its natural state, mainly due to its typical hardness and high astringency caused by the presence of soluble phenolic compounds (tannins). Consequently, flour production is the main alternative to ensure the use of green fruit by the food industry 
(Sarawong, Schoenlechner, Sekiguchi, Berghofer, \& Ng., 2014).

Green banana flour (GBF), a product obtained from the natural or artificial drying of banana, has considerable levels of protein, mineral salts, and dietary fiber (Carmo, 2015; Reis et al., 2019). It has been widely used in the preparation of functional foods by the industry, especially in the production of bakery and dietetic products, making it a known source of RS and mineral salts (Vernaza, Gularte, \& Chang, 2011; Campuzano et al., 2018). The consumption of high fiber foods is associated with prevention of diseases such as cancer, diabetes, and cardiovascular disease, as well as lowering LDL cholesterol levels (Veronese et al., 2018).

According to the Brazilian Association of Industrialized Biscuits, Pasta, Bread \& Cakes, cake sales have steadily grown each year. In 2020, Brazil occupied the 12 th position globally and sold 205,000 t of cakes (Associação Brasileira de Massas Alimentícias, Pães e Bolos Industrializados [ABIMAPI], 2021).

Due to the great popularity of cakes, several studies have been conducted aiming at their nutritional enrichment (Bitencourt, Dutra, Pinto, Helbig, \& Borges, 2014; Urrutia et al., 2019; Eggea et al., 2020; Gouvea, Maciel, Carvalho, Boas, \& Nachtigall, 2020). The consumption of these fortified foods can contribute important nutrients to the population's diet, such as fiber, vitamins, and minerals. In the case of enrichment with RS, studies associate its consumption with benefits related to reducing the risk of cardiovascular diseases and contributing to the modulation of cholesterol, especially LDL, and triglycerides, as it is a carbohydrate that is not digested by the digestive process that also has functional properties similar to those performed by fibers (Ranieri \& Delani, 2014; Öztürk \& Mutlu, 2019).

This study developed a cake formulation containing GBF rich in resistant starch and good sensory acceptance.

\section{Materials and Methods}

\section{Green banana flour production}

Cultivar BRS SCS Belluna was used to obtain the GBF used in the present study. The flour was prepared according to Reis et al. (2019), at the Food Science and Technology Laboratory at Embrapa Cassava \& Fruits, located in Cruz das Almas - Bahia, Brazil.

Step 1: Development and selection of a formulation

\section{Cake processing}

Four cake formulations were elaborated (Table 1), and the most sensory accepted one was used as a starting point for developing new formulations in step 2 . 
Table 1

Cake formulations developed in step 1 of the study

\begin{tabular}{|ccccc|}
\hline Ingredient (\%) & E1F1 & E1F2 & E1F3 & E1F4 \\
\hline GBF* & 17.57 & 16.05 & 16.46 & 15.12 \\
\hline Oat flour & 20.27 & 18.52 & 18.99 & 17.44 \\
\hline Eggs & 29.46 & 26.91 & 27.59 & 25.35 \\
\hline Raw sugar & 10.81 & 9.88 & 10.13 & 9.30 \\
\hline Baking powder & 1.08 & 0.99 & 1.01 & 0.93 \\
\hline Coconut milk & 20.27 & 18.52 & 18.99 & 17.44 \\
\hline Cinnamon powder & 0.54 & 0.49 & 0.51 & 0.47 \\
\hline $50 \%$ cocoa powder & --- & --- & 6.33 & 5.81 \\
\hline Dried banana & --- & 8.64 & --- & 8.14 \\
\hline
\end{tabular}

*GBF - green banana flour; E1F1 - control (no dried banana or 50\% cocoa powder); E1F2 - formulation with dried banana; E1F3 - formulation with 50\% cocoa powder; E1F4 - formulation with 50\% cocoa powder and dried banana.

The ingredients were weighed individually and homogenized until a homogeneous dough was obtained, which was later baked in a rectangular pan at $200^{\circ} \mathrm{C}$ for $25 \mathrm{~min}$.

\section{Sensory evaluation}

The study was approved by the Research Ethics Committee (authorization registered under the number CAAE: 17106213.1.0000.0053).

The sensory evaluation of the cake was performed by 47 untrained assesors. The tests were conducted in individual booths, on the same day the cakes were produced. Samples were served in pieces of $4 \times 4 \mathrm{~cm}$, inside a paper liner for mini-cakes that was encoded with three-digit random numbers. Acceptability was evaluated regarding color, aroma, flavor, texture/softness attributes, and overall acceptance, using a nine-point hedonic scale ranging from "I extremely dislike" to "I extremely like", according to Stone and Sidel (2010). Approval percentages for sensory attributes were calculated based on the sum of scores equal to or greater than six. The purchase intention was evaluated using a fivepoint scale anchored from "would certainly buy" (5) to "would certainly not buy" (1). The five-point ideal scale was also applied to evaluate the sweetness and texture/softness attributes, as described by V. L. P. Ferreira et al. (2000) and Berilli et al. (2011).

\section{Stage 2: Development and evaluation of new formulations with different GBF contents}

\section{Cake processing}

The E1F4 formulation, which contained $15.43 \%$ GBF was used as a starting point for the proposal of four new formulations, aiming to increase the RS content of the product, as shown in Table 2. The GBF contents of the new formulations maintained the approximate proportions of $14,18,22$, and $26 \%$ GBF. A cake without GBF (control) was also prepared to compare its composition with the other formulations. 
Table 2

Formulations of cakes with different GBF contents developed in step 2 of the study

\begin{tabular}{|c|c|c|c|c|c|}
\hline Ingredient (\%) & Control & E2F1 & E2F2 & E2F3 & E2F4 \\
\hline Oat flour & 28.67 & 14.95 & 11.06 & 6.55 & 2.25 \\
\hline $\mathrm{GBF}^{*}$ & - & 13.72 & 17.61 & 22.12 & 26.42 \\
\hline Eggs & 22.32 & 22.32 & 22.32 & 22.32 & 22.32 \\
\hline Raw sugar & 8.19 & 8.19 & 8.19 & 8.19 & 8.19 \\
\hline Baking powder & 0.82 & 0.82 & 0.82 & 0.82 & 0.82 \\
\hline Coconut milk & 27.30 & 27.30 & 27.30 & 27.30 & 27.30 \\
\hline Cinnamon powder & 0.41 & 0.41 & 0.41 & 0.41 & 0.41 \\
\hline $50 \%$ cocoa powder & 5.12 & 5.12 & 5.12 & 5.12 & 5.12 \\
\hline Dried banana & 7.17 & 7.17 & 7.17 & 7.17 & 7.17 \\
\hline
\end{tabular}

*GBF - green banana flour; Control - without GBF; E2F1 - 14\% GBF; E2F2 - 18\% GBF; E2F3 - 22\% GBF; E2F4 - 26\% GBF.

\section{Physicochemical evaluation and proximate composition}

These analyses were conducted only for the cake formulations developed in the second step of the study.

The cakes were subjected to color analysis using the Konica Minolta ${ }^{\circledR}$ colorimeter and the CIELAB color system. The device was calibrated with a white ceramic plate, using the D65 illuminant $(z=93.6 ; x=0.3133 ; y=0.3195)$. The parameters of L* (lightness), $C^{*}$ (chroma), $\mathrm{h}^{*}$ (hue), $\mathrm{a}^{*}$ (green/red component) and $\mathrm{b}^{*}$ (blue/yellow component) were evaluated.

Moisture, ash, and protein contents were also determined according to Instituto Adolfo Lutz [IAL] (2008).

Lipids were quantified following the method proposed by Bligh and Dyer (1959). Total carbohydrates were estimated as the difference between 100 and the sum (in percentage terms) of moisture, ash, lipid, protein, and fiber values. The total calorific value was calculated from the proximate composition data, using the conversion factors of $4 \mathrm{kcal}$ for carbohydrates and protein and 9 kcal for lipids (Araújo \& Menezes, 2005).

The RS content was obtained as proposed by Goñi, Garcia-Diz, Eva and Calixto (1996); the main steps of analysis consisted of the removal of proteins and digestible starch as well as enzymatic solubilization and hydrolysis of the RS, for its subsequent quantification as released glucose.

The total dietary fiber content was determined by the AOAC 985.29 enzymaticgravimetric method (Prosky, Asp, Devries, Schweizer \& Harland, 1985).

Three experimental replicates were conducted, and each analysis was performed in triplicate.

\section{Sensory evaluation}

In step 2, the sensory acceptance test was performed, on a laboratory scale, by 45 untrained assessors. The test was conducted 
in a randomized-block design in which the same evaluations described in item 2.3 were performed. In this step, the four formulations containing GBF were served to the assessors.

\section{Statistical analysis}

Three experimental replicates were carried out in a completely randomized design to produce the cakes, and the physicochemical evaluation data were subjected to analysis of variance. In the case of a significant $F(p<0.05)$, means were compared by Tukey's test at 5\% probability, using SISVAR software version 5.3 (D. F. Ferreira, 2010).

For the sensory evaluation, a randomized-block design was followed, where each assessor represented an experimental replicate.
Results and Discussion

Step 1 - Development and selection of a formulation

\section{Sensory evaluation of the cake}

Table 3 shows the results of the sensory acceptance test and the approval percentages (scores from 6 to 9) of the cakes made with GBF. There were differences between the formulations for the five attributes evaluated.

In terms of color, the assessors preferred formulations E1F3 and E1F4, which included $50 \%$ cocoa powder in common, which shows that consumers prefer the dark brown color of the cake. Fasolin, Almeida, Castanho and Netto Oliveira (2007) developed cookies with GBF and reported a similar consumer behavior, with a preference for the darker cookies.

\section{Table 3}

\section{Average hedonic values and approval percentage of cakes with GBF}

\begin{tabular}{|c|c|c|c|c|c|c|c|c|c|c|}
\hline \multirow[t]{2}{*}{ Formulation } & \multicolumn{2}{|c|}{ Color } & \multicolumn{2}{|c|}{ Aroma } & \multicolumn{2}{|c|}{ Flavor } & \multicolumn{2}{|c|}{$\begin{array}{l}\text { Texture/ } \\
\text { softness } \\
\end{array}$} & \multicolumn{2}{|c|}{$\begin{array}{c}\text { Overall } \\
\text { acceptance }\end{array}$} \\
\hline & Avg. ${ }^{1}$ & $\mathrm{Apv}^{2}$ & Avg. ${ }^{1}$ & $\mathrm{Apv}^{2}$ & Avg. ${ }^{1}$ & $\mathrm{Apv}^{2}$ & Avg. ${ }^{1}$ & $\mathrm{Apv}^{2}$ & Avg. ${ }^{1}$ & $\mathrm{Apv}^{2}$ \\
\hline E1F1 & $5.71^{\mathrm{b}}$ & 66.67 & $6.06^{c}$ & 64.44 & $5.68^{c}$ & 57.78 & $5.56^{c}$ & 62.22 & $5.57^{c}$ & 59.09 \\
\hline E1F2 & $6.00^{\mathrm{b}}$ & 71.11 & $6.68^{b}$ & 82.22 & $6.73^{b c}$ & 84.44 & $6.33^{b c}$ & 73.33 & $6.62^{\mathrm{b}}$ & 86.67 \\
\hline E1F3 & $7.77^{a}$ & 97.78 & $6.70^{\mathrm{b}}$ & 80.00 & $6.40^{\mathrm{ab}}$ & 80.00 & $5.96^{\mathrm{ab}}$ & 68.89 & $6.55^{b}$ & 82.22 \\
\hline E1F4 & $7.90^{\mathrm{a}}$ & 100 & $7.24^{\mathrm{a}}$ & 86.67 & $7.40^{\mathrm{a}}$ & 95.45 & $6.90^{a}$ & 82.22 & $7.50^{\mathrm{a}}$ & 97.78 \\
\hline
\end{tabular}

E1F1 - control (without the addition of dried banana or $50 \%$ cocoa powder); E1F2 - formulation with dried banana; E1F3 - formulation with 50\% cocoa powder; E1F4 - formulation with dried banana and 50\% cocoa powder; (1) Average of hedonic scores $(n=47)$ on a nine-point scale; (2) Approved; results expressed as a percentage of scores $\geq 6$. Means followed by common letters in the column do not differ at $5 \%$ by Tukey's test.

Formulation E1F4 showed greater acceptance in terms of aroma, differing statistically from the others, with an average score of 7.24 and an approval percentage of $86.67 \%$. Indeed, the combination of dried banana with $50 \%$ cocoa powder provided an aroma that pleased the cake consumers.

The consumers noticed a significant difference in flavor between formulations E1F1 and E1F4, with a higher percentage of 
approval for the E1F4 (95.45\%). This result indicates that the addition of $50 \%$ cocoa powder and bananas contributed positively to improving the flavor of the formulations, and the association of the two ingredients provided the best result for this attribute. The same observation can be made for texture/softness and overall acceptance, as the approval percentages increased due to the addition of dried banana and 50\% cocoa powder. Formulation E1F4 presented the highest score for overall acceptance, indicating the preference of the assessors for this formulation. In general, formulation E1F1 had a lower acceptance percentage (above 57\%) for all evaluated attributes. The results indicate that the use of GBF in cake formulations is promising from a sensory point of view, especially when associated with $50 \%$ cocoa powder and dried banana.

Regarding the ideal scale, most consumers considered the sweetness of formulations E1F2 and E1F4 to be ideal (Figure

1A). Considering dried banana as the common ingredient in these two formulations is, it can be concluded that this ingredient positively interfered with the acceptance of the product's sweetness. Texture/softness was considered not very soft in formulations E1F1, E1F2 and E1F3; however, formulation E1F4 stood out in this attribute, with most assessors classifying it as ideal (Figure 1B).

Figure 2 illustrates the results of the purchase intention of the cakes. Adding the "would certainly buy" and "would probably buy" categories, the highest purchase intent is seen for formulation E1F4 (75.55\%) and the lowest for formulation E1F1 (22.22\%), corroborating the acceptance test (Table 3).

Formulation E1F4 was the most accepted for all evaluated attributes and showed ideal sweetness and texture/softness as well as high purchase intent. Therefore, it was chosen as the starting point for developing four different new formulations, which contained the same ingredients, in step 2.
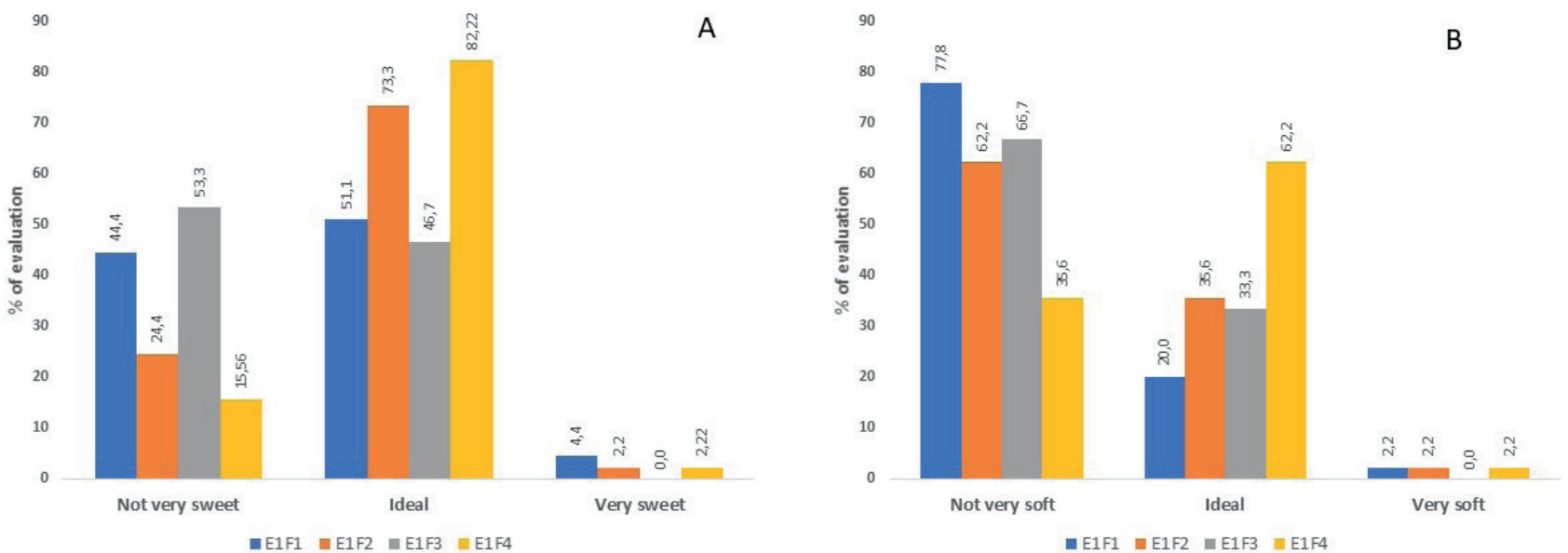

Figure 1. Evaluation of sweetness (A) and texture/softness (B) of cakes made with GBF by assessors*, according to the ideal scale.

E1F1 - control (without the addition of dried banana or $50 \%$ cocoa powder); E1F2 - formulation with dried banana; E1F3 - formulation with 50\% cocoa powder; E1F4 - formulation with dried banana and $50 \%$ cocoa powder; Percentage of scores ${ }^{*} n=47$. 


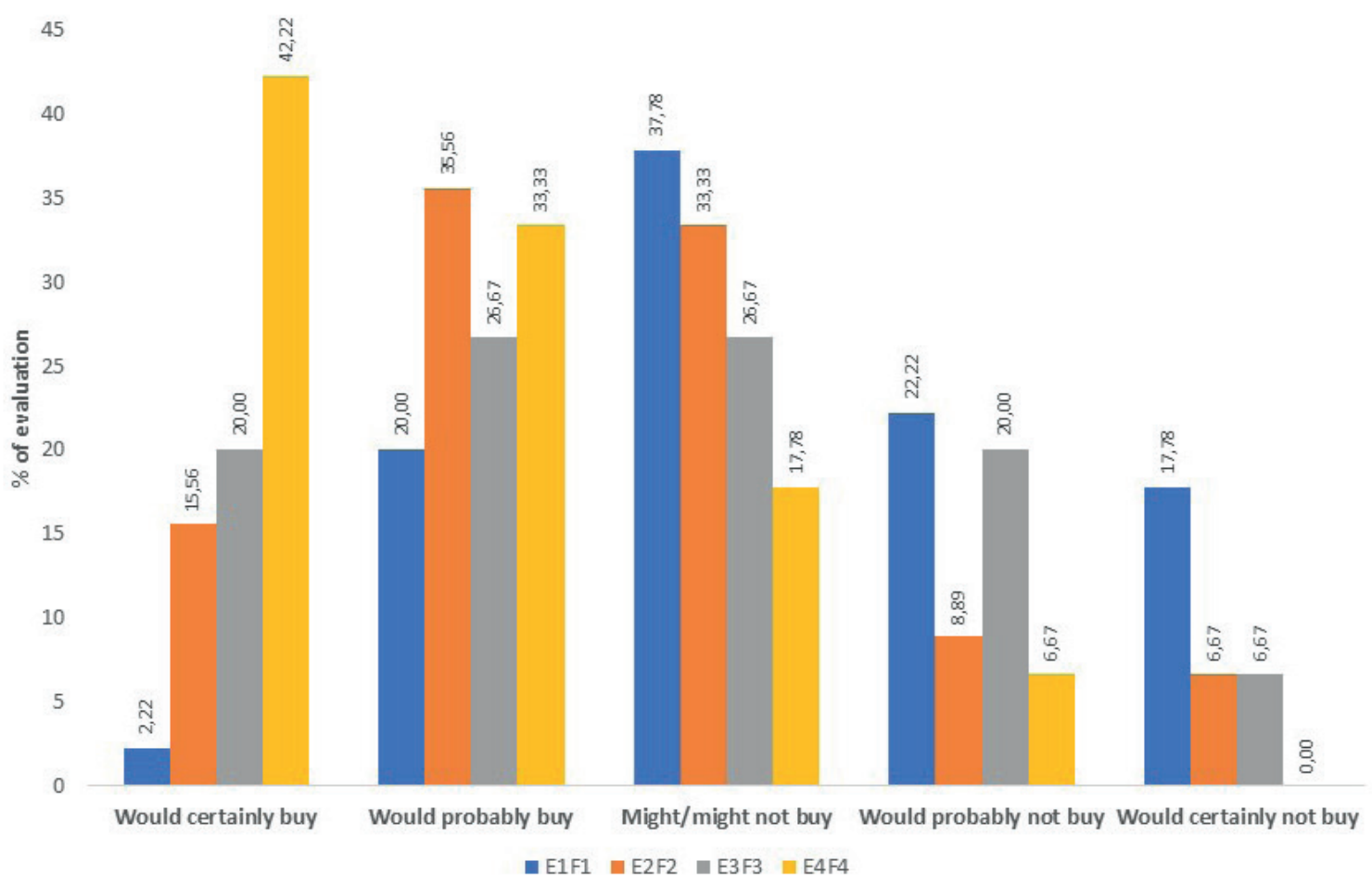

Figure 2. Purchase intent for cakes made with GBF by assessors*.

E1F1 - control (without the addition of dried banana or $50 \%$ cocoa powder); E1F2 - formulation with dried banana; E1F3 - formulation with $50 \%$ cocoa powder; E1F4 - formulation with dried banana and $50 \%$ cocoa powder; Percentage of scores ${ }^{*} n=47$.

\section{Stage 2- Development and evaluation of new formulations with different GBF contents}

\section{Physicochemical characterization and proximate composition of the cakes}

The addition of GBF to the cake formulations increased the RS content (Table 4). The observed increase was of the orders of 7.2, 8.3, 14.9, and 17.9 times, respectively, in formulations E2F1, E2F2, E2F3 and E2F4, relative to the control. Andrade, Perius, Mattos, Luvielmo and Mellado (2018) used GBF associated with whole wheat flour to prepare whole wheat bread and reported that the formulations with higher GBF contents (15\% and $20 \%$ ) had significantly higher RS contents when compared with the control formulation.

A higher ash value was detected in formulation E2F4 compared with E2F1 and E2F2, suggesting that this formulation is the richest in minerals. Borges, Pereira and Lucena (2009) reported that GBF has a high mineral content when compared with other types of flours on the market, which may explain the increase in ash content as the concentration of GBF in the cakes was increased. In contrast, Viana, Souza, Reis and Oliveira (2018) found no difference in ash content after using different concentrations of GBF (15\%, 20\%, and $25 \%)$ in the partial replacement of wheat flour in sliced bread. 


\section{Table 4}

Physicochemical characteristics of cakes made with GBF

\begin{tabular}{|ccccccc|}
\hline Evaluated trait & E2F1 & E2F2 & E2F3 & E2F4 & Control & Mean \\
\hline Resistant starch (\%) & $2.31^{\mathrm{c}}$ & $2.67^{\mathrm{c}}$ & $4.77^{\mathrm{b}}$ & $5.73^{\mathrm{a}}$ & $0.32^{\mathrm{d}}$ & $3.16^{*}$ \\
\hline Ash (\%) & $1.96^{\mathrm{b}}$ & $1.96^{\mathrm{b}}$ & $2.11^{\mathrm{ab}}$ & $2.22^{\mathrm{a}}$ & $2.08^{\mathrm{ab}}$ & $2.07^{*}$ \\
\hline Lipids (\%) & $10.48^{\mathrm{ab}}$ & $8.78^{\mathrm{ab}}$ & $9.74^{\mathrm{ab}}$ & $8.49^{\mathrm{b}}$ & $11.58^{\mathrm{a}}$ & $9.81^{*}$ \\
Moisture (\%) & 32.23 & 32.76 & 34.17 & 33.12 & 34.01 & $33.26^{\text {ns }}$ \\
Protein (\%) & $8.07 \mathrm{~b}$ & $7.34 \mathrm{c}$ & $6.84^{\text {cd }}$ & $6.63^{\mathrm{d}}$ & $9.48^{\mathrm{a}}$ & $7.67^{*}$ \\
\hline Total dietary fiber (\%) & 9.85 & 10.80 & 8.90 & 9.85 & 7.10 & $9.30^{\text {ns }}$ \\
\hline Carbohydrates (\%) & 36.50 & 37.40 & 36.41 & 39.04 & 35.74 & $37.02^{\text {ns }}$ \\
\hline Total calorific value (kcal 100 g-1) & 272.76 & 252.50 & 264.84 & 259.75 & 284.41 & $266.85^{\text {ns }}$ \\
\hline $\mathrm{L}^{*}$ & 31.66 & 32.53 & 30.41 & 31.5 & 30.44 & $31.37^{\text {ns }}$ \\
$\mathrm{a}^{*}$ & 9.45 & 10.35 & 9.6 & 9.4 & 9.35 & $9.65^{\text {ns }}$ \\
$\mathrm{b}^{*}$ & 10.88 & 13.11 & 10.99 & 11.31 & 10.37 & $11.4010^{\text {ns }}$ \\
$\mathrm{C}^{*}$ & 14.42 & 16.71 & 14.48 & 14.66 & 13.97 & $14.91^{\text {ns }}$ \\
$\mathrm{h}^{*}$ & 48.79 & 51.7 & 48.75 & 49.96 & 47.96 & $49.54^{\text {ns }}$
\end{tabular}

E2F1 - 14\% GBF; E2F2 - 18\% GBF; E2F3 - 22\% GBF; E2F4 - 26\% GBF; Control - without GBF.

n. s. = not significant at $5 \%$ by Tukey's test; ${ }^{*}=$ significant at $5 \%$ by Tukey's test. Means followed by common letters in the rows do not differ at $5 \%$ by Tukey's test.

There was also a significant difference in the lipids and protein contents of the formulations (Table 4). Lipids were highest in the control formulation (11.58\%) and lowest in formulation E2F4 (8.49\%). Protein results were similar, with the highest content occurring in the control formulation (9.48\%), which decreased as the GBF content in the formulations was increased. This result can be explained by the fact that the formulation of control treatment includes a greater amount of oat, an ingredient with a higher lipid and protein content relative to GBF. According to Sandrin (2013), oat is a cereal whose structure is different from the others, and in addition to having a high lipid content distributed throughout the entire grain, it is also rich in protein. Unlike the present study, Freitas et al. (2017) did not observe significant differences in the lipid and proteins levels in honey breads made with $30 \%$ cooked GBF (banana varieties Prata and Grande Naine) partially replacing wheat flour.

The mean values of $L^{*}, a^{*}, b^{*}, C^{*}$, and $h^{*}$ showed that the cake had an intense dark brown color. There was no significant difference between the formulations for these variables (Table 4) since 50\% cocoa powder the main ingredient responsible for the color was used in the same proportion in all formulations.

The use of different concentrations of GBF in the formulations did not interfere with moisture, which averaged $33.26 \%$ (Table 4). This value was close to the $35.5 \%$ found by Galeano and Rezende (2013), who developed a cake formulation with $15 \%$ passion fruit peel flour. The moisture content found by Chiareli, Silva, Marchiori and Mello (2017), who 
developed a cake formulation containing oat flour and chia grains, was $33.49 \%$, a value also similar to that found in the present study. It is important to emphasize that products with high moisture favor the development of deteriorating microorganisms, directly influencing the product's shelf life.

There was no variation in the content of total dietary fiber (mean value of $9.30 \%$ ) or carbohydrates (mean value of $37.02 \%$ ) (Table 4). In the study by Chiareli et al. (2017), who developed a cake based on oat flour and chia, the results for dietary fiber and carbohydrates were $8.59 \%$ and $31.03 \%$, respectively. These values were relatively close to those found in the present study.

InBrazil, the Ministry of Healthallows the designation of "fiber source" for industrialized products that contain at least $2.5 \mathrm{~g}$ of fiber per serving (ANVISA, 2012). Considering that the portion of cake in Brazil is $60 \mathrm{~g}$ (ANVISA, 2003), it can be considered that the consumption of a portion of the food prepared in this study will bring benefits to health, as it would contribute $5.58 \mathrm{~g}$ of fiber to the diet.
The caloric values of the four formulations did not differ, either, with a mean value of $266.85 \mathrm{kcal} 100 \mathrm{~g}^{-1}$ (Table 4). In the study by Carneiro (2015) to evaluate a cake formulation based on oat, quinoa, and flaxseed

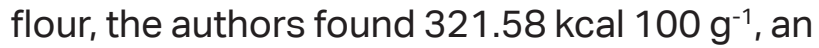
energy value higher than that obtained in this study.

Based on the presented results, the addition of GBF to the cake did not change its physicochemical traits or proximate composition, but considerably increased its RS content, suggesting that it is a functional ingredient that can be added to increase the nutritional value of the product.

\section{Sensory evaluation}

Sensory evaluation was carried out only with formulations that included GBF in their composition. There was no significant difference between the cakes for the attributes of color or aroma, and approval percentages were above $77 \%$ for all formulations, indicating high acceptance of these attributes (Table 5).

\section{Table 5}

Average hedonic values of cakes prepared with different GBF concentrations

\begin{tabular}{|c|c|c|c|c|c|c|c|c|c|c|}
\hline \multirow[t]{2}{*}{ Formulation } & \multicolumn{2}{|c|}{ Color } & \multicolumn{2}{|c|}{ Aroma } & \multicolumn{2}{|c|}{ Flavor } & \multicolumn{2}{|c|}{$\begin{array}{l}\text { Texture/ } \\
\text { softness }\end{array}$} & \multicolumn{2}{|c|}{$\begin{array}{c}\text { Overall } \\
\text { acceptance }\end{array}$} \\
\hline & Avg. $^{1}$ & Apv. $^{2}$ & Avg. ${ }^{1}$ & $\mathrm{Apv}^{2}$ & Avg. ${ }^{1}$ & $\mathrm{Apv}^{2}$ & Avg. $^{1}$ & $\mathrm{Apv}^{2}$ & Avg. ${ }^{1}$ & $\mathrm{Apv}^{2}$ \\
\hline E2F1 & 7.64 & 97.78 & 6.80 & 82.22 & $6.80 a$ & 84.44 & 6.36a & 75.56 & $6.73 a$ & 82.22 \\
\hline E2F2 & 7.60 & 97.78 & 6.93 & 84.44 & $6.73 a$ & 80.00 & $6.00 a$ & 62.22 & $6.62 a$ & 80.00 \\
\hline E2F3 & 7.62 & 100.00 & 6.87 & 82.22 & $6.16 b$ & 71.11 & $5.51 b$ & 60.00 & $6.20 b$ & 77.78 \\
\hline E2F4 & 7.51 & 100.00 & 6.69 & 77.78 & $5.62 b$ & 60.00 & $4.93 b$ & 51.11 & $5.84 b$ & 68.89 \\
\hline Mean & $7.59^{\text {n.s. }}$ & - & $6.82^{\text {n.s. }}$ & - & $6.33^{*}$ & - & $5.70^{*}$ & - & $6.35^{*}$ & - \\
\hline CV (\%) & 0.007 & - & 0.015 & - & 0.087 & - & 0.108 & - & 0.064 & - \\
\hline
\end{tabular}

E2F1 - 14\% GBF; E2F2 - 18\% GBF; E2F3 - 22\% GBF; E2F4 - 26\% GBF.

n.s. = not significant at $5 \%$ probability by the $\mathrm{F}$ test; ${ }^{*}=$ significant at $5 \%$ probability by Tukey's test; ( $\left.{ }^{1}\right)$ Average of hedonic scores ( $n=45$ ) on a nine-point scale; (2) Approved; percentage of scores $\geq 6$. Means $(n=45)$ followed by common letters in the column do not differ at $5 \%$ by Tukey's test. 
Interms of flavor, therewas a preference for the formulations with lower levels of GBF (E2F1 and E2F2), whose approval percentages were both higher than $80 \%$. For the texture/ softness attribute, formulations E2F1 and E2F2 were also highlighted, achieving greater acceptance (greater than 62\%). Finally, the overall acceptance item confirms the preference for these formulations, with over $80 \%$ of approval (Table 5).

Because the four formulations only differed in the GBF and oat contents, the addition of GBF above $18 \%$ was found to reduce the acceptance of the attributes of taste and texture/softness, as well as overall acceptance (Table 5). Loong and Woong (2018) also observed less texture acceptance in steamed Chinese breads after incorporating $15 \% \mathrm{GBF}$ in the formulations, with mean values between 5.2 and 6.71 .

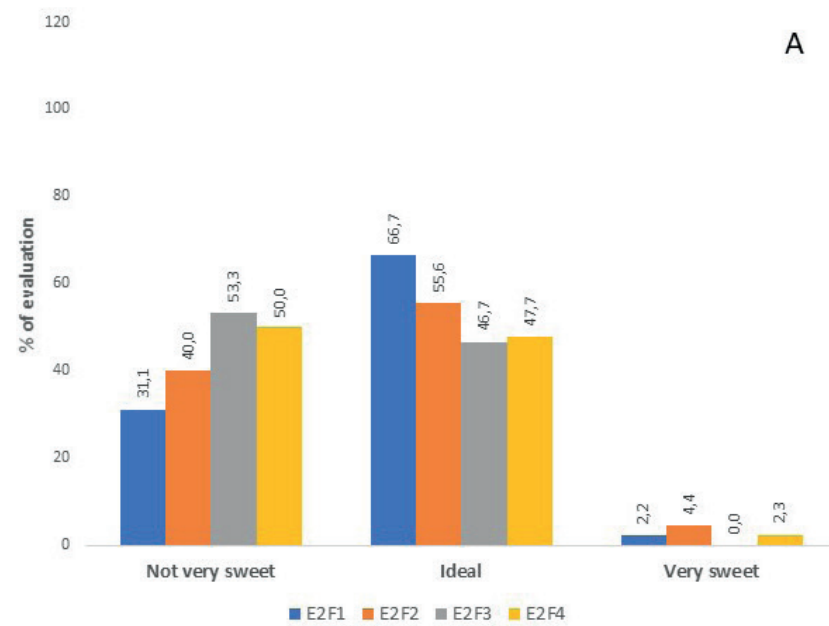

C. K. O. Andrade (2013) found a similar result after preparing cookies enriched with GBF at the concentrations of $10 \%, 20 \%$, and $30 \%$. The author described greater acceptance for those with 10\% GBF and a reduction in acceptance in those with 30\% of the ingredient, demonstrating that the assessors preferred cookies with lower levels of GBF, probably because they resemble other cookies usually consumed.

Although the raw sugar content in the four formulations was the same, most assessors considered the sweetness of the formulations with 14\% (E2F1) and 18\% (E2F2) GBF to be ideal, with acceptance values of $66.7 \%$ and $55.6 \%$ (Figure $3 \mathrm{~A}$ ), respectively, whereas the formulations with $22 \%$ GBF (E2F3) and $26 \%$ GBF (E2F4) were considered as having ideal sweetness by $46.7 \%$ and $47.7 \%$ of assessors, respectively.

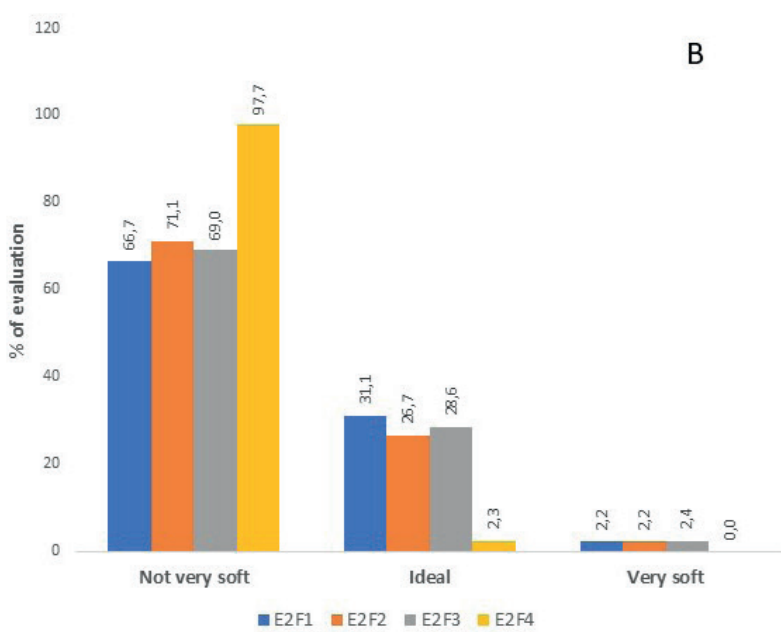

Figure 3. Evaluation of sweetness (A) and texture/softness (B) of cakes made with different concentrations of GBF by assessors*, according to the ideal scale GBF: green banana flour; E2F1 - 14\% GBF; E2F2 - 18\% GBF; E2F3 - 22\% GBF; E2F4 - 26\% GBF; ${ }^{*} \mathrm{n}=45$ 
As for the ideal scale, regarding the texture/softness attribute, all formulations were considered not very soft (Figure 3B), and the formulation with the highest GBF content (E2F4) was considered the least soft by $97.7 \%$ of assessors.

This result occurred because products without wheat flour tend to be harder than products made with common wheat flour.

In this respect, Vieira, Freitas, Silva and Barbosa (2015) conducted a study on the effect of replacing wheat flour in the preparation of gluten-free cookies with cassava starch, soy flour, quinoa, and amaranth flour. Sensory analysis revealed, regarding the texture attribute, a higher preference for the control cookie (based on wheat flour), which allows us to conclude that the other flours used in the study also changed the texture characteristics of the cookies, reducing their acceptance by consumers.

Figure 4 shows the results of the purchaseintentiontestofthe cakeformulations. Adding the scores of "would certainly buy" and "would probably buy" categories, a reduction is observed in purchase intent as the GBF content in the product is increased, with $53.33 \%$ of consumers stating they would buy the cake containing $14 \%$ GBF, while only $24.24 \%$ would buy the cake containing $26 \%$ GBF.

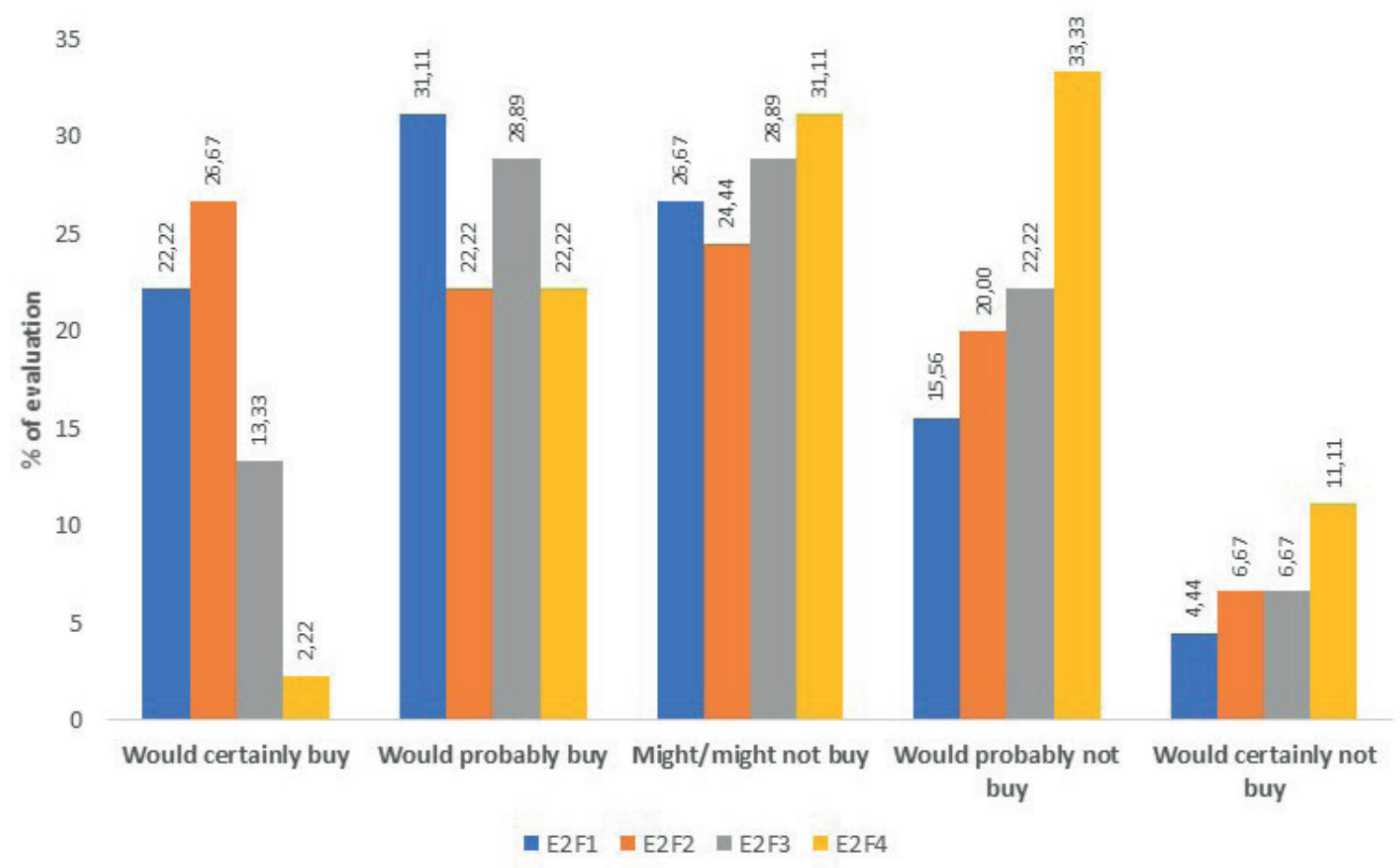

Figure 4. Purchase intent for cakes made with different concentrations of GBF by assessors. E2F1 - 14\% GBF; E2F2 - 18\% GBF; E2F3 - 22\% GBF; E2F4 - 26\% GBF; *n=45 


\section{Conclusions}

The addition of 14 and $18 \%$ green banana flour to the formulations contributed to the development of products of high sensory acceptance, high purchase intent, and resistant starch contents 7.2 and 8.3 times higher, respectively, than those in the cake without the addition of green banana flour.

\section{Acknowledgments}

The authors thank the Foundation for Research Support of the State of Bahia (FAPESB), Brazil (projects no. 731/2014 and 2796/2018; Quota 2018), the National Council for Scientific and Technological Development (CNPq) (project no. 441467/2014) and the Brazilian Agricultural Research Corporation for financial support.

\section{References}

Andrade, B. A., Perius, D. B., Mattos, N. V., Luvielmo, M. M., \& Mellado, M. S. (2018). Produção de farinha de banana verde (Musa spp.) para aplicação em pão de trigo integral. Brazilian Journal of Food Technology, 21, e2016055. doi: 10.15 90/1981-6723.5516

Andrade, C. K. O. (2013). Elaboração e aceitabilidade dos biscoitos enriquecidos com farinha de banana verde. Trabalho de conclusão de curso, Univerdade Estadual da Paraíba, Catolé do Rocha, PR, Brasil. Recuperadodehttp://dspace.bc.uepb.edu. br/jspui/bitstream/123456789/2126/1/ PDF\%20-\%20Crisnia\%20Kaliane\%20 Oliveira\%20Andrade.pdf
Araújo, E. M., \& Menezes, H. C. (2005). Composição centesimal, lisina disponível e digestibilidade in vitro de proteínas de fórmulas para nutrição oral ou enteral. Ciência e Tecnologia de Alimentos, 25(4), 768-771. doi: 10.1590/S0101-20612005 000400023

Associação Brasileira de Massas Alimentícias, Pães e Bolos Industrializados (2021). Bolos industrializados - vendas (milhão tons). Recuperado de https://www.abima pi.com.br/estatisticas-paes-e-bolos.php

Berilli, S. S., Almeida, S. B., Carvalho, A. J. C., Freitas, S. J., Berilli, A. P. C. G., \& Santos, P. C. (2011). Avaliação sensorial dos frutos de cultivares de abacaxi para consumo in natura. Revista Brasileira de Fruticultura, 33, 592-598. doi: 10.1590/S0100-2945 2011000500081

Bitencourt, C., Dutra, F. L. G., Pinto, V. Z., Helbig, E., \& Borges, L. R. (2014). Elaboração de bolos enriquecidos com semente de abóbora: avaliação química, física e sensorial. Boletim do Centro de Pesquisa de Processamento de Alimentos, 32(1), 19-32. doi: 10.5380/cep.v32i1.36927

Bligh, E. G., \& Dyer, W. J. (1959). A rapid method of total lipid extraction and purification. Canadian Journal Biochemistry Physiological, 27(8), 911-917. doi: 10.11 39/y59-099

Borges, A. M., Pereira, J., \& Lucena, E. M. P. (2009). Caracterização da farinha de banana verde. Ciência e Tecnologia de Alimentos, 29(2), 333-339. doi: 10.1590/ S0101-20612009000200015

ANVISA. Agência Nacional de Vigilância Sanitária (2003, dezembro 23). Aprova o Regulamento Técnico de Porções 
de Alimentos Embalados para Fins de Rotulagem Nutricional (Resolução RDC no 359, de 23 de dezembro de 2003). Diário Oficial da União. Recuperado de http://portal.anvisa.gov.br/documents/ 33880/2568070/res0359_23_12_2003. pdf/76676765-a107-40d9-bb34-5f05a e897bf3

ANVISA. Agência Nacional de Vigilância Sanitária (2012, novembro 12). Dispõe sobre o Regulamento Técnico sobre Informação Nutricional Complementar (Resolução RDC n 54, de 12 de novembro de 2012). Diário Oficial da União. Recuperado de http://bvsms.saude.gov. br/bvs/saudelegis/anvisa/2012/rdc0054 _12_11_2012.html

Campuzano, A., Rosell, C. M., \& Cornejo, F. (2018). Physicochemical and nutritional characteristics of banana flour during ripening. Food Chemistry, 256, 11-17. doi: 10.1016/j.foodchem.2018.02.113

Carmo, A. F. S. (2015). Propriedades funcionais da biomassa e farinha de banana verde. Trabalho de conclusão de curso, Universidade de São Paulo, Lorena, SP, Brasil. Recuperado dehttps://sistemas.eel. usp.br/bibliotecas/monografias/2015/ MBI15005.pdf

Carneiro, G. S. (2015). Caracterização físicoquímica de bolos com substituição parcial da farinha de trigo por aveia, quinoa e linhaça. Enciclopédia Biosfera, 11(21), 3348-3355.

Chiareli, C. A., Silva, J. C., Marchiori, J. M. G., \& Mello, M. H. G. (2017). Desenvolvimento de um bolo rico em fibras solúveis enriquecido com chia. Revista Ciências Nutricionais Online, 1(1), 46-52.
Eggea, V., Medeiros, C. O., Queiroz, C., Anjos, M. C. R., Sereno, A. B., \& Bertin, R. L. (2020). Development and acceptability of cocona (Solanum sessiliflorum Dunal) added chocolate cake. Research, Society and Development, 9(2), 1-9. doi: 10.33448/ rsd-v9i2.1973

Fasolin, L. H., Almeida, G. C., Castanho, P. S., \& Netto Oliveira, E. R. (2007). Biscoitos produzidos com farinha de banana: avaliações química, física e sensorial. Ciências e Tecnologia de Alimentos, 27(3), 524-529. doi: 10.1590/S0101-20 612007000300016

Ferreira, D. F. (2010). SISVAR - Sistema de análise de variância. Versão 5.3. Lavras, MG: UFLA.

Ferreira, V. L. P., Almeida, T. C. A. de, Pettinelli, M. L. C. de V., Silva, M. A. A. P., Chaves, J. B.P., \& Barbosa, E. M. M. (2000). Análise sensorial: testes discriminativos e afetivos. (Manual: Série Qualidade). Campinas: SBCTA.

Ferronatto, A. N., Rossi, R. C., \& Cappellari, F. (2020). Amido resistente: alternativa de alimento funcional para a homeostase da glicose, redução do perfi I lipídico e modulação da microbiota intestinal. Revista Saúde e Desenvolvimento Humano, 8(2), 109-120. doi: 10.18316/sdh

Freitas, M. C. J., Silveira, G. E. da, Veras, L. S., \& Santos, G. F. F. (2017). Pães de mel elaborados com farinha de diferentes variedades de banana verde. Demetra, 12(2), 465-482. doi: 10.12957/demetra. 2017.25127

Galeno, G. N., \& Rezende, A. J. (2013). Avaliação físico-química de bolos com diferentes níveis de farinha da casca de maracujá. Revista de Divulgação Científica Sena Aires, 2(2), 129-133. 
Goñi, I., Garcia-Diz, L., Eva, M., \& Calixto, S. (1996). Analysis of resistant starch: a method for foods and food products. Food Chemistry, 56(4), 445-449. doi: 10.1016/0308-8146(95)00222-7

Gouvea, I. F. S., Maciel, M. P. R., Carvalho, E. E. N., Boas, B. M. V., \& Nachtigall, A. M. (2020). Caracterização física e química de farinha de talo de beterraba. Brazilian Journal of Development, 6(3), 15814-15823. doi: 10.34117/bjdv6n3-452

Instituto Adolfo Lutz (2008). Normas analíticas do Instituto Adolfo Lutz. Métodos químicos e físicos para análise de alimentos (4a ed.). São Paulo: Instituto Adolfo Lutz.

Loong, C. Y. L. \& Wong, C. Y. H. (2018). Chinese steamed bread fortified with green banana flour. Food Research, 2(4), 320330. doi: 10.26656/fr.2017.2(4).058

Öztürk, S., \& Mutlu, S. (2019). Physicochemical properties, modifications, and applications of resistant starches. In M. T, P. Cleirici \&, M. Schimiele (Eds.), Starches for food application: chemical, technological and health properties (pp. 297-332). Academic Press.

Pires, V. C. F., Silva, F. L. H. \& Souza, R. M. S. (2014). Parâmetros da secagem da banana pacovan e caracterização físico-química da farinha de banana verde. Revista Verde de Agroecologia e Desenvolvimento Sustentável, 9(1), 197-209.

Prosky L., Asp, N.-G, Furda I. , Devries J. W., Schweizer, T. F.\& Harland, B. F. (1985). Determination of total dietary fiber in foods and food products: collaborative study. Journal of the Association Official Agricultural and Chemists. 68(4), 677679. doi: doi.org/10.1093/jaoac/68.4.677
Ranieri, L. M.; Delani, T. C. O. (2014). Banana verde (Musa spp): obtenção da biomassa e ações fisiológicas do amido resistente. Uningá Review, 20(3), 43-49.

Reis, R. C., Viana, E. S., Assis, S. L., Sena, L. O., Souza, A. S., \& Amorim, E. P. (2019). Promising green banana and plantain genotypes for making flour. Pesquisa Agropecuária Brasileira, 54, e01303. doi: 10.1590/s1678-3921.pab2019.v54. 01303

Sandrin, R. (2013). Caracterização físicoquímica de diferentes frações da aveia (Avena Sativa L.) e atividade antioxidante de seus extratos. Tese de doutorado, Universidade Federal de Santa Catarina, SC, Brasil. Recuperado de https://repositorio.ufsc.br/handle/123 456789/122576

Sarawong, C., Schoenlechner, R., Sekiguchi, K., Berghofer, E., \& Ng, P. K. W. (2014). Effect of extrusion cooking on the physicochemical properties, resistant starch, phenolic content and antioxidant capacities of green banana flour. Food Chemistry, 143, 33-39. doi: 10.1016/j. foodchem.2013.07.081

Stone, H., \& Sidel, J. (2010) Sensory evaluation practices (vol. 6, 3nd ed.). New York: Academic Press.

Urrutia, M. A., Ramos, A. G., Horst, M., Sacks, T., Bedin, B., \& Bernardi, D. M. (2019). Formulação de bolos enriquecidos com farinhas produzidas com subprodutos da laranja. Fag Journal of Health, 1(2), 121129. doi: 10.35984/fjh.v1i2.101

Vernaza, M. G., Gularte, M. A., \& Chang, Y. K. (2011). Addition of green banana flour to instant noodles: rheological and 
technological properties. Ciência e Agrotecnologia, 35(6), 1157-1165. doi: 10.1590/s1413-70542011000600016

Veronese, N., Solmi, M., Caruso, M. G., Giannelli, G., Osella, A. R., Evangelou, E.,... Tzoulakl, I. (2018). Dietary fiber and health outcomes: an umbrella review of systematic reviews and meta-analyses. The American Journal of Clinical Nutrition, 107(3), 436-444. doi: 10.1093/ajcn/nqx082
Viana, E. S., Souza, A. S., Reis, R. C., \& Oliveira, V. J. S. (2018). Application of green banana flour for partial substitution of wheat flour in sliced bread. Semina: Ciências Agrárias, 39(6), 2399-2408. doi: 10.54 33/1679-0359.2018v39n6p2399

Vieira, T.S., Freitas, F. V., Silva, L. A. A., \& Barbosa, W. M. (2015). Efeito da substituição da farinha de trigo no desenvolvimento de biscoitos sem glúten. Brazilian Journal of Food Technology, 18(4), 285-292. doi: 10.1590/1981-6723.1815 